\title{
Sacralisation: Defying the Politicisation of Security in Turkey ${ }^{1}$
}

\author{
Pinar Bilgin \\ Bilkent University
}

\begin{abstract}
In early 2016, a small town called Kilis on Turkey's southeast border became the target of unguided short-range rockets originating from an ISIS-controlled zone in Syria. Continuing over a five-month period, the attacks claimed 20+ lives, rendered hundreds of people homeless, and traumatised many more. Yet, the public in the rest of Turkey remained mostly unaware of the havoc caused by these attacks. This is not to say that appropriate steps to address the rocket attacks were not taken. Yet uttering 'security' was conspicuously absent from Ankara's response repertoire. The puzzle being: how was it possible for Ankara to limit politics in the face of local civil societal actors' and opposition MPs' attempts to politicise security? Through sacralisation, I suggest. What follows shows that in the first half of 2016, invoking 'sacred' cultural codes in framing the events helped Ankara to limit politics around security.
\end{abstract}

Keywords: Securitisation; politicisation; sacred; politics; security; Turkey

\section{Introduction}

In early 2016, a small town called Kilis on Turkey's southeast border became the target of unguided short-range rockets originating from an ISIS-controlled zone in Syria. Continuing over a five-month period, the attacks claimed $20+$ lives, rendered hundreds of people homeless, and traumatised many more. Yet, the public in the rest of Turkey remained mostly unaware of the havoc caused by these attacks. This is not to say that appropriate steps to address the rocket attacks were not taken. Yet this was done without any political drama. Uttering 'security' was conspicuously absent from Ankara's response repertoire.

A first look at the Kilis incident seems to suggest a textbook-worthy example of the social constructedness of security: rockets sent from outside a country's

1 An early version of this paper was presented at the workshop 'The Politicization of Security: Controversy, Mobilisation, Arena-Shifting', ETH Zurich, May 31-June 1 2018. I would like to thank all the participants and especially the guest editors for their feedback. 
boundaries and resulting in fatalities may not be securitised if the state elite chooses to portray them as 'falling'. ${ }^{2}$

A second look shows that Ankara did securitise the issue but without recourse to security-speak. The local and central representatives of the state adopted a series of measures to prevent further destruction and alleviate human suffering while putting in place a gag order on the use of graphic images in media reporting. ${ }^{3}$

A third look reveals that Ankara's efforts did not concern a decision to securitise or not (because the issue was already securitised), but were in defiance of local civil societal actors' and opposition MPs' attempts to politicise security via generating controversy: the former issued an announcement in national newspapers declaring that 'the homeland is under attack' and invited attention; the latter set up an investigative commission and submitted written questions at the Parliament, probing into the appropriateness of Ankara's handling of the incident. ${ }^{4}$

My aim here is not to inquire into the possible reasons why Ankara responded to ISIS rockets in the way it did. ${ }^{5}$ Others have considered the relative weight of domestic and international political concerns in shaping Ankara's policies toward the war in Syria in general and ISIS in particular. ${ }^{6}$ Here, I am interested in understanding how it was possible for Ankara to defy local non-state actors' and opposition MPs' attempts to politicise security. What follows shows that in the first half of 2016, representatives of the state establishment invoked 'sacred' cultural codes when framing the dangers involved in and the suffering caused by the rocket attacks. In the face of local civil societal actors and opposition MPs seeking to generate controversy around Ankara's handling of the incident, I suggest, invoking 'sacred' cultural codes in framing the events helped to limit politics around security.

The paper begins by tracing the trajectory of critical security thinking about politicisation of security (section 1) and offers a discussion on the notion of sacralisation (section 2). Next, I set the context in Turkey by showing how the late 1990s and early-to-mid 2000s were characterised by politicisation of security by civil societal actors who sought to make room for the democratising reforms

2 'Cumhurbaşkanlığı Sözcüsü Büyükelçi İbrahim Kalın’ın Basın Toplantısında Yaptığı Açıklama' https://www. tccb.gov.tr/cumhurbaskanligi-sozculugunden/1695/43734/cumhurbaskanligi-sozcusu-buyukelci-ibrahimkalinin-basin-toplantisinda-yaptigi-aciklama (Accessed 18 May 2018).

3 'Başbakan Yardımcısı Kurtulmuş: Kilis için ilave askeri tedbirler alınacak' https://www.aa.com.tr/tr/politika/ basbakan-yardimcisi-kurtulmus-kilis-icin-ilave-askeri-tedbirler-alinacak/561254 (Accessed 4 July 2018).

4 'Kilis is under attack, the homeland is under attack', the announcement placed in the newspapers read. See, 'İsyan eden Kilisliler gazeteye ilan verdi: acele edin ölüyoruz', http://kentgazetesi.biz/isyan-eden-kilislilergazeteye-ilan-verdi-acele-edin-oluyoruz/ (Accessed 3 May 2018). On the opposition's attempts at generating controversy, see: 'CHP Heyeti Kilis Raporunu Açıkladı' http://kentgazetesi.biz/chp-heyeti-kilis-raporunuacikladi/ (Accessed 23 May 2018); https://www.tbmm.gov.tr/develop/owa/yazili_sozlu_soru_gd.onerge_ bilgileri?kanunlar sira no=199927 (Accessed 6 July 2018).

5 In 2014, Turkey's Mosul (Iraq) consulate was seized by ISIS, keeping 49 people hostages (including the consul-general) for three months until a negotiated deal was reached. A report issued by the Ministry of Interior listed 14 major terrorist attacks conducted by ISIS in Turkey during 2014-16. Turkey has been a member of the coalition fighting ISIS since the beginning. The İncirlik airbase in Turkey has been used by the coalition in the fight against ISIS since 2015. See https://www.academia.edu/33832608/T\%C3\%BCrkiyenin_DAE\%C5\%9E_ ile_M\%C3\%BCcadelesi___Turkeys_Fight_Against_DEASH (Accessed 6 July 2018).

6 See, for example, Haldun Yalcinkaya, "Foreign Fighters of ISIS and Their Security Threat: Turkey's Experience (2014-2016)," Uluslararasi Iliskiler-International Relations 14, no. 53 (2017); Burak Kadercan, "What the ISIS Crisis Means for the Future of the Middle East," in Non-State Armed Actors in the Middle East: Geopolitics, Ideology, and Strategy, ed. Murat Yeşiltaş \& Tuncay Kardaş (Cham: Springer International Publishing, 2018); Asli S. Okyay, "Turkey's Post-2011 Approach to Its Syrian Border and Its Implications for Domestic Politics," International Affairs 93, no. 4 (2017). 
required by EU conditionality. Such reforms were previously obstructed by those in the state establishment who invoked 'national security' concerns toward limiting politics (section 3). The final section turns to the Kilis incident in early 2016 and shows how Ankara, when faced with non-state actors' and the opposition's efforts to generate a controversy around its handling of the Kilis incident, responded by portraying as 'sacred' the dangers involved in and the suffering generated by the attacks (section 4).

\section{Politicising security}

On one level, to speak of politicising security is a misnomer. Security is always already political. To quote R.B.J. Walker: 'questions about security cannot be separated from the most basic questions of political theory'. ${ }^{7}$ Michael Dillon concurred:

Security turns-out to have a much wider register - has always and necessarily had a much wider register, something which modern international security studies have begun to register - than that merely of preserving our so-called basic values, or even our mortal bodies. That it has, in fact, always been concerned with securing the very grounds of what the political itself is; specifying what the essence of politics is thought to be. ${ }^{8}$

On another level, post-Cold War debates on security were set in motion by exposing the politics of Security Studies that had, for long, remained oblivious to its own politics. What students of critical approaches to security have done, then, is to expose the politics of (the study of) security. ${ }^{9}$ As Ken Booth underlined, 'the problem of security is not in the meaning of the concept, but in the politics of the meaning'. ${ }^{10}$ Dillon's counsel that Security Studies scholars begin to register the ways in which security has a 'much wider register' was considered to be an appropriate opening move by students of critical approaches to security. ${ }^{11}$

In the early post-Cold War period, exposing the politics of security went hand in hand with highlighting the constructedness of security. ${ }^{12}$ Notwithstanding the differences among students of critical approaches to security, they all begin from the understanding that insecurities are socially constructed. ${ }^{13}$ This is not about materiality/ immateriality of issues. What is socially constructed is their securityness/not. The decisive factor is neither the material costs incurred nor the breach of sovereignty. What renders an issue a 'threat' is not its intrinsic qualities but the meanings ascribed

7 R. B. J. Walker, “The Subject of Security," in Critical Security Studies: Concepts and Cases, ed. Keith Krause \& Michael C. Williams (Minneapolis, MN: University of Minnesota Press, 1997), 63.

8 Michael Dillon, Politics of Security: Towards a Political Phiosophy of Continental Thought (Routledge, 2002), 13.

9 'Politicizing security' and 'exposing the politics of security' are difficult to distinguish in the way 'gendering security' refers to 'exposing the ways security is gendered'. I use them interchangeably.

10 Ken Booth, Theory of World Security (Cambridge: Cambridge University Press, 2007), 101.

11 K. M. Fierke, Critical Approaches to International Security, 2nd ed. (Oxford: Wiley, 2015), Ch.1. Also see, Stefano Guzzini, "The Dual History of 'Securitisation'," DIIS working paper (Copenhagen: Danish Institute for International Studies, 2015).

12 Jutta Weldes, Mark Laffey, Raymond Duvall \& Hugh Gusterson, eds., Cultures of Insecurity: States, Communities and the Production of Danger (Minneapolis: University of Minnesota Press, 1999).

13 Bill McSweeney, Security, Identity and Interests: A Sociology of International Relations (Cambridge: Cambridge University Press, 1999). 
by social actors. The broader point being, the decision (securitise/not) is political through and through.

Beyond exposing the politics of Security Studies and inquiring into the constructedness of security, students of critical approaches concur in considering security-speak to be a 'magic wand' that makes available to the state elite a broader menu of options so that the issue under consideration could be addressed swiftly and beyond democratic scrutiny. ${ }^{14}$ When the state elite utters 'security' about an issue (and goes without challenge by the relevant audience) it becomes possible for the state establishment to adopt 'extraordinary measures'. If the state elite does not resort to security-speak about an issue, it is presumed to be content with addressing it within democratic processes, equipped with a smaller menu of options and lesser resources.

That said, Copenhagen School securitisation theory pointed to another likelihood about the sequence of events in that securitisation without uttering security is possible: if and when the securityness of the issue has already been institutionalised. The example Barry Buzan, Ole Waever and Jaap De Wilde offered was the Dutch solution to floods: the dikes. They wrote:

Constant drama does not have to be present, because it is implicitly assumed that when we talk of this (typically, but not necessarily, defense issues), we are by definition in the area of urgency: By saying 'defense'(or, in Holland, 'dikes'), one has also implicitly said security and priority. ${ }^{15}$

The process of institutionalisation was further elaborated on by Didier Bigo, who maintained that securitisation is not restricted to uttering (or implying, as above) 'security' but includes a 'mix of discursive and non-discursive practices' that involve 'centrally bureaucratic and technological practices, implying categorisations, classifications, and boundary formations among the labels of security, insecurity, freedom etc'. ${ }^{16}$ Issues may be securitised, then (with little or no political drama) when bureaucratic actors operate behind the scenes to put into effect practices designed by technocratic actors.

In the decade following the end of the Cold War, security practices of various actors seemed to meet Copenhagen School securitisation theory's expectations regarding de-securitisation. To quote Carsten Bagge Lautsen \& Ole Waever:

14 As formulated in: Ole Waever, "Security, the Speech Act: Analysing the Politics of a Word," COPRI Working Paper (Copenhagen: Copenhagen Peace Presearch Institute, 1989); "Securitization and Desecuritization". The notion of 'securitization' is adopted by most if not all students of critical approaches to security. They disagree on the utilization and implications of securitization. See, Ken Booth, "Security and Emancipation," Review of International Studies 17, no. 4 (1991); "Security and Self: Reflections of a Fallen Realist," in Critical Security Studies : Concepts and Cases, ed. Keith Krause \& Michael C. Williams (Minneapolis: University of Minnesota Press, 1997); Critical Security Studies and World Politics (Boulder: Lynne Rienner Publishers, 2005); Theory of World Security; Claudia Aradau, "Security and the Democratic Scene: Desecuritization and Emancipation," Journal of International Relations \& Development 7, no. 4 (2004); Anthony Burke, "Security Cosmopolitanism," Critical Studies on Security 1, no. 1 (2013); Barry Buzan, Ole Waever, \& Jaap De Wilde, Security: A New Framework of Analysis (Boulder, CO: Lynne Rienner, 1998); Didier Bigo, "International Political Sociology," in Security Studies: An Introduction, ed. Paul D. Williams (London: Routledge, 2008).

15 See, Buzan, Waever \& De Wilde, 27.

16 Bigo 129. 
the ideal of the securitization approach is - ceteris paribus - de-securitization, that issues are not lifted above normal politics with an urgency and "necessity" that often has anti-democratic effects. ${ }^{17}$

During the 1990s, EU membership candidates went through security sector reform as part of the accession process. ${ }^{18}$ In the Global South, governments and regimes faced Northern donors' calls for democratic control of the armed forces and desecuritisation of issues such as human rights. ${ }^{19}$ As a part of the EU accession process, Turkey, too, came under pressure to re-calibrate civil military relations to institute a slimmed down security agenda under civilian governance. ${ }^{20}$

Since 9/11, however, space for 'normal' politics has become circumscribed, albeit to different degrees in different parts of the world. In the United States, the Department of Homeland Security was created, bringing together a number of already existing institutions under one roof. ${ }^{21}$ The passing of the Patriot Act meant the invoking of extraordinary powers for the use of security agencies, the extent of which became known only after the Snowden revelations. ${ }^{22}$ In Western Europe, some governments supplemented security with risk in governing terrorism, with different implications for citizens, immigrants and asylum-seekers. ${ }^{23}$ In the Global South, EU donors' calls for security sector reform were increasingly overlooked by local leaders who jumped on the bandwagon of the Global War on Terror (GWoT). In North Africa, for instance, authoritarian leaders (some of whom did not survive the Arab uprisings) found a new lease of life after 9/11, as they collaborated with the United States and its European allies within the framework of GWoT. ${ }^{24}$

That said, post-9/11 developments did not bring an end to myriad actors' engagements with politics around security (although with different degrees of autonomy or achievement). Hence the empirical starting point of this special issue as laid out in the Introduction: what has been observed in different parts of the world in recent years may not be captured within the bounds of the securitisation/ de-securitisation binary, but through inquiring into the politicisation of security -i.e. the 'politicisation perspective'.

To link the discussion here to the problem of the paper, what is puzzling about the Kilis incident does not concern a decision (securitise/not). For, Ankara's handling

17 Carsten Bagge Laustsen and Ole Wæver, "In Defence of Religion: Sacred Referent Objects for Securitization," Millennium: Journal of International Studies 29, no. 3 (2000): 708.

18 David Spence \& Philipp Fluri, eds., The European Union and Security Sector Reform (Geneva: DCAF \& John Harper Publishers, 2008).

19 Gavin Cawthra \& Robin Luckham, eds., Governing Insecurity: Democratic Control of Military and Security Establishments in Transitional Democracies (London: Zed Books, 2003).

20 These developments were invariably read as de-securitization by closer observers of Turkey. For a discussion of this literature, see Pinar Bilgin, "The Politics of Studying Securitization? The Copenhagen School in Turkey," Security Dialogue 42, no. 4-5 (2011).

21 David Cole, "We Kill People Based on Metadata," The New York Review of Books 10 (2014); George W Bush, "Address to the Nation on the Proposed Department of Homeland Security," Weekly Compilation of Presidential Documents 38, no. 23 (2002).

22 Laura Poitras, "Citizenfour" (Praxis Films, 2014).

23 Claudia Aradau \& Rens Van Munster, "Governing Terrorism through Risk: Taking Precautions,(Un) Knowing the Future," European journal of international relations 13, no. 1 (2007).

24 Ulla Holm, "The EU's Security Policy Towards the Mediterranean: An (Im)Possible Combination of Export of European Political Values and Anti-Terror Measures?," DIIS Working Papers, no. 2004/13 (2004); Pinar Bilgin, "Temporalizing Security: Securing the Citizen, Insecuring the Immigrant in the Mediterranean," in Time, Temporality and Violence in International Relations: (De) Fatalizing the Present, Forging Radical Alternatives, ed. Anna M. Agathangelou and Kyle D. Killian (London: Routledge, 2016). 
of the fallout involved securitisation of the issue through the use of the bureaucratic mechanisms of the state. ${ }^{25}$ The puzzle here is understanding how it was possible for Ankara to defy local civil societal actors' and opposition MPs' attempts to generate controversy around its handling of the situation. As noted above, the paper suggests that this was achieved by invoking 'sacred' cultural codes when framing the incident, which helped to limit politics around security.

\section{Sacralisation}

Sacralisation is a process of rendering things 'sacred', to move them beyond everyday political deliberation, even as they are utilised as a source of legitimacy by political actors. Throughout history, 'sacred' has served as 'a source of legitimacy for political rule, while at the same time remaining always beyond politics and law', ${ }^{26}$ Sacralisation of things is different from the securitisation of religion in that the two may have different referents. When religion is securitised, the referent is either a religion, or its believers, or a particular model of relating religion to politics (as in politicised religion, see below). ${ }^{27}$ When things are sacralised, it is political actors and their politics regarding that 'thing' that is being safeguarded against would-be challengers.

Then, sacralisation functions in a manner similar to securitisation insofar as both limit politics. Yet while 'politics around security' has become a routine occurrence over the years (as discussed in the Introduction to this special issue), the 'sacred' continues to be treated as remaining beyond politics. Indeed, just as Cold War Security Studies was oblivious to its own politics, those who invoke 'sacred' cultural codes remain silent about their own politics. Arguably, this is because both those who want to avoid politics based on religion, and those who seek legitimacy by invoking sacred cultural codes, have refrained from contesting the presumed autonomy of religion from politics. Hence the need for adopting a sociologically informed approach to the 'sacred' in the study of politics and security. Such a move has the potential to allow students of Security Studies to move away from studying religion as either a threat to or a referent of security and considering what rendering things 'sacred' does in discussions on politics and security. ${ }^{28}$

It is important to note here that secularisation of world politics ${ }^{29}$ did not bring an end to political actors' recourse to 'sacred' cultural codes in limiting politics. Indeed, what renders the notion of sacralisation particularly interesting is when it is utilised

25 Ankara's response does not come under Copenhagen School's definition of pre-established securitization. This is because the state establishment took special care to portray the rockets as 'falling' (and not as 'attacks') thereby leaving open the possibility that there may not be a threat that requires defensive measures. See section 4 for further discussion.

26 Friedrich Kratochwil, "Politics, law, and the sacred: a conceptual analysis," in Semantics of Statebuilding, ed. Nicolas Lemay-Hébert, et al. (London: Routledge, 2013), 49.

27 Bagge Laustsen \& Wæver, 722.

28 Renato Moro, "Religion and Politics in the Time of Secularisation: The Sacralisation of Politics and Politicisation of Religion," Totalitarian Movements and Political Religions 6, no. 1 (2005). V. Jane Lindsay, "Learning from Their Mistakes: Some Implications of International Relations Scholarship for the Study of Religion," Journal of Contemporary Religion 29, no. 2 (2014).

29 Peter L. Berger, The Sacred Canopy: Elements of a Sociological Theory of Religion (New York: Anchor Books, 1967). 
by political actors in secularised contexts. For, in those settings where some version of politicised religion is in power (as in Iran, Saudi Arabia or Afghanistan), there is little need for (studying) sacralisation. ${ }^{30}$ Challenges to policy-making in such settings are already thwarted by virtue of the securityness of religion being pre-established and institutionalised (as with Buzan et al's examples of defense and Dutch dikes, see above).

Over the years, students of politics studying sacralisation in secularised contexts have looked at how warfare has contributed to the making of nations as 'a sacred community of sacrifice' ${ }^{31}$ or how particular sites have been transformed into tourist attractions through 'sight sacralisation'.$^{32}$ Venezuela's populist president Hugo Chavez is understood to have frequently utilised 'the cultural dimension of religion [to] inform secular claims making' ${ }^{33}$ Scholarly research into Serbia's leader Slobodan Milosevic's and Russia's president Vladimir Putin's discourses suggest that both have sacralised historically contested territories that they made claims on. ${ }^{34}$

To focus on the latter example, when Milosevic and Putin, respectively, sacralised Kosovo and Crimea, they did so as a 'strategy of de-contestation' so that they could 'refuse to address the political question as to who should control the land'. In so doing, Milosevic and Putin sought to

depoliticize the contest over territory. Since the territory is sacred to one group, no political argument as to who should, in fact, control the territory can, within this kind of nationalist discourse, be decisive... The sacred is taken to be simply above and beyond the political. And yet the sacralization of land...is a political rhetorical device used in political speeches -in an attempt to depoliticize the topic which is being addressed. ${ }^{35}$

The point being, sacralisation moves issues beyond everyday political deliberation, not because there is no politics to those issues (or to the decision to sacralise/not), but because 'sacred' continues to be treated as remaining beyond politics in myriad settings.

Consider the 2003 US-led war on Iraq. The initial case for the war was made by the US state elite by pointing to the threat constituted by a potentially advanced Iraqi Weapons of Mass Destruction (WMD) program. ${ }^{36}$ Once the war began and little evidence of the suspected Iraqi advances in producing a nuclear bomb could be found, sacralisation of the war effort helped the White House to defy its critics. As Bülent Diken and Carsten Bagge Laustsen argued, the ground-work was already prepared for the sacralisation of the 2003 war. Highlighting how it is in the secular context of the United States that sacralisation has served to limit politics, Diken and Bagge Lautsen wrote,

30 Bagge Laustsen \& Wæver, 722.

31 John Hutchinson, "Warfare and the Sacralisation of Nations: The Meanings, Rituals and Politics of National Remembrance," Millennium: Journal of International Studies 38, no. 2 (2009).

32 Elizabeth C. Fine \& Jean Haskell Speer, "Tour Guide Performances as Sight Sacralization," Annals of tourism research 12 , no. 1 (1985).

33 José Pedro Zúquete, “The Missionary Politics of Hugo Chávez," Latin American Politics and Society 50, no. 1 (2008).

34 Aleksandar Pavković, "Sacralisation of Contested Territory in Nationalist Discourse: A Study of Milošević's and Putin's Public Speeches," Critical Discourse Studies 14, no. 5 (2017).

35 Pavković, 509.

36 US Secretary of State Colin Powell's UN address is available here: https://www.theguardian.com/world/2003/ feb/05/iraq.usa. (Accessed 4 July 2018). 
the values of the covenant which are supposed to be spread worldwide are not faith, charity, salvation, love, praying and other core ideas found in 'regular religions' but rather liberal and civic values and virtues such as liberty, equality, justice, rule of law and freedom - in short, the values embodied in the constitution. By treating the democratic system and its embodied values as sacred it becomes difficult for Americans to understand why people could desire anything else. Thus, as Britons considered it 'a white man's burden' to penetrate dark continents to rid the world of its sicknesses, the Americans are now trying to rid the world of terrorists and wicked dictators. ${ }^{37}$

During the 2003 war, invoking 'sacred' cultural codes such as the 'manifest destiny' of the United States to bring democracy to the Middle East (or 'save' women in Afghanistan) helped the political actors to defend the policy choices they made in defiance of their critics' attempts at politicising security. ${ }^{38}$

Section 4 of the paper offers a reading of Ankara's resort to 'sacred' cultural codes in framing the Kilis incident in early 2016 as an effort that helped to limit politics around security in the face of political actors seeking to generate a controversy regarding its handling of the events. The following section sets the context in Turkey by looking at the late 1990s and early-to-mid 2000s, a period characterised by some civil societal actors' efforts to politicise Turkey's definition of 'national security', which they considered to be too broad and statist. During this period, a coalition of actors generated controversy surrounding the definition of 'national security' toward making a case for the democratising reforms required by EU conditionality. As will be seen, Turkey's dynamics during the late 1990s and early-to-mid 2000s come across as supporting the special issue editors' case for a politicisation perspective in the study of politics and security.

\section{Politicising security in Turkey - late 1990s and early 2000s}

While Turkey's military has never shied away from expressing its will, intervening directly in 1960 and indirectly in 1971 (via memorandum), it was after the 1980 intervention that governing through security was institutionalised. ${ }^{39}$ Although direct military rule lasted for three years after the coup, the institutions and practices that were set in place during this period remained for longer. It was those institutions and practices that allowed for the so-called 'post-modern coup' of 1997 where the military acted behind the scenes, through making inroads into aspects of the civil society and state bureaucracy. ${ }^{40}$

37 Bülent Diken \& Carsten Bagge Laustsen, "We Two Will Never Twin": Fundamentalism and the Politics of Security," Global Society 20, no. 2 (2006), 212.

38 The literature on 'civil religion' or 'political religion' is rich and well-established. Scholars who study sacralisation typically draw on this literature. See, for example, Emilio Gentile and Robert Mallett, "The sacralisation of politics: definitions, interpretations and reflections on the question of secular religion and totalitarianism," Totalitarian movements and political religions 1, no. 1 (2000).

39 Gencer Özcan, "Doksanlarda Türkiye'nin Ulusal Güvenlik Ve Dış Politikasında Askeri Yapının Artan Etkisi," in En Uzun on Yıl, Türkiye'nin Ulusal Güvenlik Ve Dış Politika Gündeminde Doksanlı Yıllar, ed. Gencer Özcan \& Şule Kut (İstanbul: Büke, 2000).

40 Ümit Cizre-Sakallığlu, "The Anatomy of the Turkish Military’s Political Autonomy," Comparative politics (1997). 
The 1982 constitution, which was prepared undermilitary tutelage, institutionalised the already significant role played by the military in shaping Turkey's politics. This role was executed through the military's authorship as well as implementation of the security agenda via the National Security Council (NSC). While the establishment of NSC dated back to $1962,{ }^{41}$ its role was not entrenched until the 1982 constitution, which changed its status from being an advisory body 'outlining the principles of the national security policy' to one which 'determines the views regarding the decisions on the formulation, setting, and implementation of the national security policy and maintenance of the necessary coordination'. The 1982 constitution made sure that the NSC's views no longer had the status of mere 'advice' but were to be 'included with priority in the agenda of the Council of Ministers by the Prime Minister and the necessary decisions were taken by the Council of Ministers' ${ }^{42}$

'National security' is defined by law in suitably vague terms: 'The protection and maintenance of the constitutional order, national presence, integrity, all political, social, cultural and economic interests in international field as well as against any kind of internal and external threats, of the State' ${ }^{43}$ The specifics of security agenda are only revealed to a small group, in the shape of a "national security policy document' (a.k.a. the 'red book') which is regularly updated by the National Security Council to reflect its members' appraisal of the changes in the domestic and global environment. In the aftermath of the 1980 coup, a wide range of issues were put on Turkey's national security agenda and addressed through military-focused and statist practices. $^{44}$

In the closing years of the $20^{\text {th }}$ century, politicising the authorship and substance of 'national security' proved to be an effective strategy for those civil societal actors in Turkey who sought to give an end to post-1980 regime of governance through security. ${ }^{45}$ They did so by pointing to the ways in which security is far from being the objective instrument it is purported to be, and that security politics worked differently in different contexts. ${ }^{46}$

The İstanbul-based think tank TESEV (Turkish Economic and Social Studies Foundation) played a key role in bolstering the intellectual foundation of the efforts to politicise security. During this period TESEV set up a task force, organised lectures, seminars, and conferences, and issued regular reports on security sector

41 Although antecedent institutions responsible for coordinating national defence policy existed since 1933, the 1962 body was inspired by the US example not least in the decision to shift from 'national defence' to 'national security' as the key concept organizing thinking and action.

42 Gencer Özcan, 'Milli Güvenlik Kurulu', in Almanak Türkiye 2005: Güvenlik Sektörü ve Demokratik Gözetim', ed. Ümit Cizre (İstanbul: TESEV, 2005), 31-2.

43 'Milli Güvenlik Kurulu Ve Milli Güvenlik Kurulu Genel Sekreterliği Kanunu', https://kms.kaysis.gov.tr/home/ kurum/31273065 (Accessed 18 May 2018).

44 The substance of this document is not revealed but becomes accessible through intermittent leaks to news outlets. For a news item on the 2015 version, see http:/www.milliyet.com.tr/iste-turkiye-icin-yeni-tehditgundem-2040175/ (Accessed May 18, 2018).

45 The remainder of this section draws on Pinar Bilgin, "Making Turkey's Transformation Possible:Claiming 'security-speak' - not Desecuritization!," Journal of Southeast European and Black Sea Studies 7, no. 4 (2007).

46 Münevver Cebeci, "The EU's Impact on Turkey: Democratization as Desecuritization," in The EC/EU: a world security actor? An assessment after 50 years of the external actions of the EC/EU (European Union Institute for Security Studies (EUISS), Paris 2006); Sinem Akgül Açıkmeşe, "EU Conditionality and Desecuritization Nexus in Turkey," Southeast European and Black Sea Studies 13, no. 3 (2013); E. Fuat Keyman \& Senem Aydin Düzgit, "Europeanization, Democratization and Human Rights in Turkey," in Turkey and the European Union: Prospects for a Difficult Encounter, ed. Esra LaGro \& Knud Erik Jørgensen (London: Palgrave Macmillan UK, 2007); cf. Bilgin, "The politics of studying securitization?" 
reform, democracy and security ${ }^{47}$ While it is difficult to assess the degree of TESEV's influence, the fact that Turkey's Chief of Staff chose to respond to one of their reports as part of his 2006 opening year address to the Military Academy ${ }^{48}$ is indicative of the reverberations this İstanbul-based think-tank created during the early 2000s.

Two security intellectuals were particularly active in shaping the public dialogues on politics of security in Turkey: Lieutenant General (Ret.) Şadi Ergüvenç and Ambassador (Ret.) İlter Türkmen. ${ }^{49}$ During the late 1990s and early 2000s Ergüvenç and Türkmen produced a series of opinion pieces elaborating on Turkey's existing security agenda and its future needs, identifying the slow progress of reforms as a 'threat to the future'. Their professional credentials (a retired lieutenant general and a renown retired ambassador) meant Ergüvenç and Türkmen could not be easily be dismissed on the grounds of (a lack of) mastery over security knowledge. As will be seen below, dismissal on the grounds of lack of expertise is what was experienced when a mere civilian, albeit the head of a political party, chose to intervene in these dialogues.

Politicising the authorship and substance of the security agenda turned out to be a critical first move for civil societal actors who were able to show that those who sought to block reform efforts by invoking concerns regarding 'national security' were engaged in politics whether they are open about it or not. In a subsequent move, some civil societal actors identified other issues (such as limited opportunities for growth and prosperity for a rapidly increasing population) as 'threats to Turkey's future', thereby de-centring the existing items on the security agenda. Between 1999, when the European Union declared Turkey a candidate country and 2004, when EU accession talks began, civil societal actors put unremitting pressure on successive governments to push through a series of reforms required by EU conditionality. ${ }^{50}$

At a moment when time seemed to be running out for passing the reforms required by the EU, one political party leader chose to vocalise the concerns of civil societal actors discussed above. In 2001, Mesut Y1lmaz, Deputy Prime Minister and head of centre-right ANAP (Motherland Party) tried to generate a controversy on Turkey's definition of 'national security'. I will outline Y1lmaz's intervention and the responses he received in a somewhat detailed manner, as these exchanges encapsulate the politicisation of security in Turkey during the late 1990s and early 2000s.

Addressing the 2001 ordinary congress of ANAP, Y1lmaz registered his complaint that democratising reforms were being blocked on grounds of 'national security' either by his coalition partners or the opposition and the military. Labelling the state of the affairs that Turkey's reformers were facing as 'national security syndrome', Y1lmaz suggested that including such a broad range of issues on the security agenda

47 See the TESEV webpage on this body of work: http://tesev.org.tr/en/reports/?calisma_alani_id=257 (Accessed 18 May 2018).

48 'Büyükanıt'tan 'irtica' uyarısı', http://www.bbc.co.uk/turkish/europe/story/2006/10/061002_turkey_general. shtml (Accessed May 18,2018). The TESEV report was a comprehensive handbook on the state of the security sector in Turkey. Available at: http://tesev.org.tr/en/reports/?yazar_id=539 (Accessed 18 May 2018).

49 Şadi Ergüvenç, "Turkey’s Security Perceptions," Perceptions 3, no. 2 (1998). İlter Türkmen, "Güvenlik, Ekonomi Ve Dis Politika," Foreign Policy (Turkey) (2001).

50 These efforts culminated in a media campaign called 'Avrupa Hareketi 2002' urging the parliament to move ahead with passing the reforms. At one point, the campaign installed a countdown timer in a public place by the Parliament to indicate remaining time for passing the reforms. 'Avrupa Hareketi 2002 oluşumu', https://www. ab.gov.tr/22720.html (Accessed 18 May 2018). 
brought Turkey closer to the Ba'th republics in its southeast neighbourhood, ${ }^{51}$ and not the European Union which it was seeking to join. Y1lmaz said:

National security is a concept that is about the survival of the state. It serves a contrary purpose in [our] present-day practice. It is being used to block steps that are required to secure the future of the state. Only Turkey could have managed to turn a concept that is about the survival of the state into one that threatens its very existence. If Turkey is to make headway, it needs to shake off this syndrome. The substance and requirements of this concept should be opened for debate. It is unacceptable that the steps that need to be taken for the country's progress is blocked in the name of national security. ${ }^{52}$

Unless the number of issues that were deemed off-limits for the reformers on grounds of 'national security' are reduced, insisted Y1lmaz, the kind of changes that would allow for EU membership cannot be achieved.

Y1lmaz's coalition partner, the nationalist-right MHP (National Action Party), and the General Staff, expressed their opposition to his attempt to generate a controversy over Turkey's definition of national security. 'National security policy is not founded on personal assessments', remarked National Defense Minister and MHP MP Sabahattin Çakmakoğlu: 'it is formulated by taking into consideration Turkey's strategic position and its neighbours'.$^{53}$ The General Staff rejected Y1lmaz's call, insisting that the public realm was not an 'appropriate' forum for debating 'national security'. 'It is more appropriate to discuss issues which are about the prosperity and happiness of people, on platforms which are not tainted with political interests', declared the General Staff. ${ }^{54}$ In doing so, both MHP MPs and the General Staff portrayed Yilmaz's call as if he was introducing politics to a discussion that was previously not political (just as students of Security Studies did during the Cold War, see section 1).

Y1lmaz's call found a more receptive ear in some civil societal actors. TÜSİAD (Turkish Industry and Business Association) issued a press release praising Y1lmaz's speech as a move that was 'in tune with democratic practices'. Still, TÜSİAD expressed hesitation in endorsing Y1lmaz's move, noting that generating a controversy on Turkey's security agenda might be 'ill-timed' given the country's economic situation (i.e., amidst an economic crisis). ${ }^{55}$ MAZLUMDER (The Organisation of Human Rights and Solidarity for Oppressed People) was less hesitant to back Y1lmaz and issued a public statement to this effect. ${ }^{56}$

To recap, Turkey's dynamics during the late 1990s and early-to-mid 2000s proceeded as anticipated by the politicisation perspective. Y1lmaz's call for a public debate on 'national security' helped to amplify the message of those civil societal

51 Ba'th Party (Arab Socialist Renaissance Party) was founded in 1943 calling for a single Arab socialist nation. It has been the ruling party in Syria from 1963 onwards and in Iraq from 1968 until the 2003 war.

52 'Mesut Yılmaz: Ulusal güvenlik ilerlemeye engel olmasın” Tabuları yıkarız', http://www.milliyet.com. tr/2001/08/05/siyaset/asiy.html (Accessed 18 May 2018)

53 'Defence Minister Says No Problem with National Security', BBC Monitoring International Reports. Internet. Available at http://wwwb.business.reuters.com. (Accessed 25 July 2002)

54 'Askerden "ulusal güvenlik" uyarısı', http://arsiv.ntv.com.tr/news/98537.asp (Accessed 23 May 2018); 'Basında Genelkurmay-Yılmaz gerginliği', http://www.hurriyet.com.tr/gundem/basinda-genelkurmay-yilmazgerginligi-38257074 (Accessed 23 May 2018).

55 'TÜSİAD gives cautious backing to Y1lmaz', Turkish Daily News. www.turkishdailynews.com/old editions/08_08_01/dom.htm\#d4 (Accessed 25 April 2003).

56 'Basın Açıklaması, Ankara, 8 Ağustos 2001', http://www.mazlumder.org/tr/main/faaliyetler/basinaciklamalari/1-ekim-2014-ihlal-haberleri/ulusal-guvenlik-tartismalari/8540 (Accessed 23 May 2018). 
actors who sought to politicise security. During this period, Turkey's civil societal actors were not able to de-securitise those issues that were already on the security agenda. Instead, they were able to expose the politics of composing the security agenda and the military's claim to primary authorship of that agenda. A series of reforms that were passed through the Parliament in the early 2000s allowed for a recalibration of civil-military relations through increasing the civilian members of the National Security Council and downgrading the status of NSC's views from being treated 'with priority' to 'advice to be considered' by the Council of Ministers. ${ }^{57}$

That said, civil societal actors failed to mobilise the broader public on the issues they raised. Nor were they able to sustain the pressure on policy-makers to politicise the extent of the security agenda. The implications of leaving intact a broad and statist security agenda only became visible in the years that followed, when a civilian-majority National Security Council continued to put these agenda items into practice, to the dismay of many civil societal actors.

\section{Sacralisation in practice - Kilis 2016}

On 18 January 2016, a secondary school in Kilis was hit by a rocket that was launched from a part of Syria that was then under ISIS control, marking the beginning of a series of attacks that would claim 20+ lives in the first half of the year. Kilis has a population of just under 100,000 people and has, for years, been known as a hub for illegal border trade. In the eyes of the most of the rest of Turkey, such notoriety is still the first thing that comes to mind regarding Kilis. For, Turkey's public (let alone the rest of the world) remained mostly uninformed about what Kilis residents experienced in the first half of 2016. This was not (only) because a gag order on the use of graphic images in media reporting was put in place. The events were not shrouded in secrecy. Yet, official statements displayed no drama surrounding the rockets, choosing to portray them as 'falling' ${ }^{58}$ Even as Turkey's military launched retaliatory attacks on ISIS strongholds in Syria and the government made available an aid package for Kilis, this was done with little justification and without resorting to security-speak. How was it possible for Ankara to defy local civil societal actors' and the opposition MPs' attempts to generate controversy on Ankara's security practices during the first half of 2016?

To begin from the beginning: according to media reports, the rocket that struck the secondary school on January 18 was one of three that hit Kilis. ${ }^{59}$ In the following months, myriad media outlets continued to report on rockets 'falling', with little hint of intentionality on the part of those who were launching them. That such vagueness of phrasing in media reporting may be a part of Ankara's response repertoire became more apparent when the local Governor, when asked about the incidents, quipped: 'of course [the rockets] are going to fall, gravity exists' ${ }^{60}$ A more

57 Özcan, "Milli Güvenlik Kurulu," 33.

58 Until the beginning of the operation 'Northern Shield' in the Fall of 2016, that is. See below.

59 'Kilis'te okula roket isabet etti: 1 ölü', http://www.hurriyet.com.tr/gundem/kiliste-okula-roket-isabet-etti-1olu-40041816 (Accessed 23 May 2018).

60 'Kilis Valisi: "Yer çekimi var, roketler elbette yere düşecek" sözlerim çarpıtıldı', http://t24.com.tr/haber/yercekimi-var-roketler-elbette-yere-dusecek-diyen-kilis-valisi-sozlerim-carpitildi,338966 (Accessed 23 May 2018). 
authoritative statement on the subject came from the Office of the Presidency, when the Presidential Spokesman noted that on the issue of 'falling rockets', they

received no information as to whether or not these were deliberate. As I said, there is a chaotic war environment on the Syrian side of the border. Some of these may be misfires, others may be deliberate. ${ }^{61}$

The Presidential Spokesman further clarified the context by highlighting the fact that Turkey faced 'on the other side of the border a terrorist organisation' and that 'it was possible that ISIS or other terrorist organisations could engage in operations' inside the country. ${ }^{62}$ It is significant to note that the Presidential Spokesman's explanation was offered in late April 2016. The local Governor's words were recorded in a session with a visiting delegation from the opposition around the same time. By then rockets had been 'falling' into Kilis for about four months.

This is not to say that Ankara did not take appropriate measures. The issue was securitised via utilising bureaucratic mechanisms of the state. Early on, a local court issued a gag order on the use of graphic images in media reporting. This was by no means a ban on all reporting, but a restriction imposed on the media's use of inflammatory images, citing the danger of causing public 'indignation' and 'disorder' ${ }^{63}$ Soon after the 18 January attack, Turkey's military launched the first of several retaliatory strikes. In March, an action plan was announced by the government putting into practice already established procedures by AFAD, Turkey's Disaster and Emergency Management Authority. These practices included the installation of an early-warning siren, setting up shelters for people who had fled their homes, and offering psychological support and other medical care to those affected. ${ }^{64}$ In April, the government revealed a rescue package to alleviate the material suffering generated by the attacks.

Still, some Kilis residents did not seem satisfied with Ankara's response. In early May, a group of local civil societal actors issued full-page announcements in national newspapers. The rather dramatically worded text addressed the President, the Speaker of the Parliament, Prime Minister, Ministers of Interior Affairs and National Defence, the Chief of General Staff and Turkey's public. It read:

Hear us. Respond to us. We know you have not forgotten, we know you are trying. But hurry up, we are dying...Kilis is under attack. The homeland is under attack. ${ }^{65}$

The announcement came across as an attempt by local civil societal actors to generate a controversy around Ankara's handling of the incident. But then, since the government had already taken a series of measures to address insecurities generated by the rocket attacks, what was the motivating factor here? The announcement could

61 ‘Cumhurbaşkanlığı Sözcüsü Büyükelçi İbrahim Kalın’ın Basın Toplantısında Yaptı̆̆ı Açıklama’ https://www. tccb.gov.tr/cumhurbaskanligi-sozculugunden/1695/43734/cumhurbaskanligi-sozcusu-buyukelci-ibrahimkalinin-basin-toplantisinda-yaptigi-aciklama (Accessed 5 July 2018).

62 Ibid.

63 'Kilis'teki patlamaya ilişkin yayın yasağı getirildi', http://www.trthaber.com/haber/turkiye/kilisteki-patlamayailiskin-yayin-yasagi-getirildi-230519.html (Accessed 8 May 2018).

64 'Afet ve acil durumlarda alinmasi gereken önlemler konulu eğitim töreni açiliş programin yapildi', http://www. milliyet.com.tr/afet-ve-acil-durumlarda-alinmasi-gereken-kilis-yerelhaber-1282260/ (Accessed 8 May 2018).

65 'İsyan eden Kilisliler gazeteye ilan verdi: acele edin ölüyoruz', http://kentgazetesi.biz/isyan-eden-kilislilergazeteye-ilan-verdi-acele-edin-oluyoruz/ (Accessed 18 May 2018); 'Kilis’ten gazete ilanıyla yardım çağrısı' 18 May 2016, http://bianet.org/bianet/insan-haklari/174541-kilis-ten-gazete-ilaniyla-yardim-cagrisi-kilisesesver (Accessed 3 May 2018). 
be read as a search for attention to the predicament of Kilis residents by the rest of Turkey's public which was, at the time, oblivious to the events. Alternatively, it could be argued that local civil societal actors, by declaring the 'homeland' to be 'under attack', offered an implicit critique of Ankara, who portrayed the rockets as 'falling' into Kilis. It could also be a combination of the two insofar as it was the absence of drama from Ankara's responses that allowed for Turkey's public to remain oblivious to the predicament of Kilis residents. It is difficult to know, because the newspaper announcements generated no official response from Ankara. Moreover, local civil societal actors did not follow up their attempt to generate controversy with any other public action.

Ankara's characterisation of the rockets as 'falling' also came under examination by opposition MPs. The main opposition party CHP (Republican People's Party) sent an investigative commission to Kilis to inquire into the events. The findings of the commission were shared with the public at a press conference where a series of recommendations were also announced, including placing Kilis 'under disaster/terror scope' and a creating a 'security zone...within Syria to make sure that the rockets are out of firing range, which would require an area of at least 20 kilometers' ${ }^{66}$ The opposition's report generated no official response from the government.

Similarly, an MP from HDP (Peoples' Democratic Party) brought the Presidential Spokesman's aforementioned statement to the attention of the Parliament. Submitting a written question to the Prime Minister, the HDP MP officially inquired about the source of information behind the Presidential Spokesman's characterisation of the rockets as 'falling into Kilis' and as possible 'misfires'. According to Parliamentary records, the question went unanswered. ${ }^{67}$

How was it possible for Ankara to defy local civil societal actors' and the opposition's attempts to generate a controversy around Ankara's security practices? In what follows, I look at statements by three representatives of the state establishment, the governor of Kilis, one local MP from AKP (Justice and Development Party), and the President of the Republic to highlight how they invoked 'sacred' cultural codes.

The governor's invoking of 'sacred' cultural codes included his portrayal of the rocket attacks as a certainty ('gravity exists') and recommending that Kilis residents seek divine providence in the face of danger. ${ }^{68}$ More specifically, the governor suggested in a statement made in April 2016 that people follow his example and not leave their home without performing their ablutions. ${ }^{69}$ Performing one's ablutions is a customary response among Muslims to deal with uncertainty, to build spiritual strength in the face of particularly challenging situations. For, performing ablutions is a ritual of purification, performed before prayers and in preparation for major

66 'Locals in Turkey's Kilis 'worried, scared and insecure,' says CHP report', http://www.hurriyetdailynews. com/locals-in-turkeys-kilis-worried-scared-and-insecure-says-chp-report--98486 (Accessed 23 May 2018). Also see, 'CHP Heyeti Kilis Raporunu Açıladı' http://kentgazetesi.biz/chp-heyeti-kilis-raporunu-acikladi/ (Accessed 23 May 2018).

67 https://www.tbmm.gov.tr/develop/owa/yazili_sozlu_soru_gd.onerge_bilgileri?kanunlar_sira_no=199927 (Accessed 6 July 2018).

$6810^{\text {th }}$ century scholar Al-Biruni is credited among many Muslims as well as historians of science for having devised a method for exploring gravity. As such, the local governor's pointing to the 'forces of gravity' need not be viewed as in contradiction with his references to 'sacred' cultural codes.

69 'Kilis Valisi'nin güvenlik önlemi: Abdestsiz çıkmıyoruz', http://www.cumhuriyet.com.tr/haber/turkiye/516368/ Kilis_Valisi_nin_guvenlik_onlemi_Abdestsiz_cikmiyoruz.html\# (Accessed 23 May 2018). 
life challenges by signalling one's resignation to his/her fate (especially if those challenges carry the risk of death).

One local AKP MP who was interviewed on TV after an attack that left eight people wounded, consoled the viewers that even more people could have been hurt or died if it was not for the 'rockets falling under watchful eye of God'. Here is the full statement of the local MP:

Our consolation is that we lost no more than 22 people because of over 80 falling rockets. I sincerely believe that each rocket is falling under the watchful eye of God. Because each of these rockets could have claimed tens of lives. ${ }^{70}$

Accordingly, the local MP echoed the local governor's call for remaining resolute in the face of danger by invoking 'sacred' cultural codes.

Lastly, the President visited Kilis in early July 2016. During his visit, the President called for unity in the face of adversity by invoking the sacred notion of martyrdom. Citing a verse from a well-known poem ('what makes land into a homeland is its martyrs') the President reminded the people that the fallen of Kilis (who died on the way to work, while at home or at school, out shopping, etc.) did not die in vain and that they were martyred. It is the martyrs who transform 'farmland into homeland', the President remarked. ${ }^{71}$ Without those who sacrifice their life, the President noted, the land they live on would not be a 'homeland' but remain as mere 'farmland'.

Of the three instances of 'sacred' cultural codes being utilised in discussing the Kilis incident, the President's references to martyrdom comes across as most anticipated. This is because, traditionally, Turkey's military has invoked the same 'sacred' cultural codes when portraying its fallen. Indeed, Turkey's military, which has self-identified as the guardian of secularism in the country, has at the same time embraced popular representations of the military as the 'home of the prophet' (peygamber ocağı), everyday name for conscripts as 'little Mehmet' (Mehmetçik; Mehmet being the Turkish version of Mohammed) and portrayed conscription as a 'sacred institution'. ${ }^{72}$ What is more, invoking 'sacred' cultural codes in reference to fallen civilians is not limited to discourse but has been built into Turkey's social security system. Since 2012, civilians who die as a result of terror attacks have been recognised by the state as 'civilian martyrs'. This is a status that carries a number of material and non-material privileges for the families left behind by the fallen. ${ }^{73}$

Just as Ankara offered no official response to local civil societal actors' newspaper announcements or opposition MPs' inquiries, the state elite did not receive any public response to their sacralisation of the Kilis incident. Lest it be thought that the utilisation of 'sacred' cultural codes is customary for AKP politicians (given

70 'Her roket Allah korumasıyla düşüyor', http://www.cumhuriyet.com.tr/video/video/604145/AKP_li_ milletvekili_Her_roket_Allah_in_korumasiyla_dusuyor.html\# (Accessed 6 July 2018).

71 'Erdoğan: "Bu Vatan Üzerinde Operasyon Yapmak İsteyenler, Karşılarında Milleti Buldular", 3 July 2016, https://www.haberler.com/erdogan-bu-vatan-uzerinde-operasyon-yapmak-8582586-haberi/ (Accessed 10 May 2018).

72 Ayșe Gül Altınay, The Myth of the Military Nation: Militarism, Gender, and Education in Turkey (New York: Palgrave Macmillan, 2004).

73 See, 'İşte 〈Sivil Şehit Yasasının detayları...’, https://www.cnnturk.com/2012/turkiye/03/21/iste.sivil.sehit. yasasinin.detaylari/654069.0/index.html (Accessed 4 July 2018). What comes across as somewhat unexpected in the President's portrayal of those who died during the attacks as martyrs is that while his words sacralised the death of those $20+$ Kilis residents who died in early 2016, the status of 'civilian martyr' was not conferred upon them straightaway. See: 'Kilis ‘te 13 aile "Sivil Şehit” statüsü istiyor', https://kazete.com.tr/haber/kiliste13-aile-sivil-sehit-statusu-istiyor-56010 (Accessed 4 July 2018). 
their self-identification as conservative Muslims, see below), it is important to note that by August 2016, after the operation 'North Shield' began, rockets arriving from the other side of Turkey/Syria border were no longer portrayed as 'falling' but as 'attacks' or 'terror attacks'. ${ }^{74}$

Two developments took place between early July when the President visited Kilis, and late August when the military operation began. On 15 July 2016, Ankara thwarted a coup attempt (15 July 2016). Soon afterwards, a state of emergency was declared throughout the country, which remained in effect for two years (until Summer 2018). The state of emergency meant that Ankara no longer had to resort to security-speak with reference to specific issues; the state establishment was pre-authorised to resort to emergency measures including limiting politics around security. Furthermore, by the time Turkey's military operation in Northern Syria began in late August 2018. ISIS had lost control of parts (but not all) of the territories on Turkey/Syria border to PKK and/or YPG. ${ }^{75}$ It is in a domestic and international context shaped by these two developments that Ankara began to portray the rockets arriving from the Syrian side of the border as 'attacks' by 'terrorist actors' including ISIS, PKK and YPG.

The point being that Ankara's resort to 'sacred' cultural codes in framing the dangers involved in and the suffering caused by ISIS rockets in early 2016 cannot be explained away with reference to culturalist presumptions (in view of the conservative Muslim self-identification of AKP politicians). This is not only because AKP politicians are not alone in invoking 'sacred' cultural codes in their discourse. As noted above, the military has traditionally portrayed itself as a 'sacred' institution, thereby helping to keep at bay the critics of compulsory military service. Culturalist explanations also fail in accounting for Ankara's resort to 'sacred' cultural codes in framing the Kilis incident because, by late August 2016, when the domestic and international political context had changed, Ankara switched to security-speak in justifying its operations in Northern Syria and began to portray the rockets that continued to hit Kilis as 'terror'/'attacks'. It is in this sense that I understand Ankara's resort to 'sacred' cultural codes in framing the Kilis incident not as business-asusual, but as an act that helped to limit politics around security in the face of a body of critics seeking to generate controversy regarding its handling of the events.

\section{Conclusion}

In late 1990s and early-to-mid 2000s' Turkey, politicising security turned out to be a successful strategy adopted by some civil societal actors in resisting being governed through security. For, while they were not able or willing to attempt 'speech act failures', said civil societal actors proved capable of politicising the authorship and composition of the security agenda. By the late 2000 s, the centrality of the role played

74 See, for instance the local governor's statement about an 'attack' that took place in early 2018: 'Kilis Valisi Tekinarslan'dan Kilis'e roket saldırısı hakkında açıklama', http://www.gunes.com/gundem/kilis-valisitekinarslandan-kilise-roket-saldirisi-hakkinda-aciklama-848943 (Accessed 26 October 2018). It is also worth noting that, by then, a new governor was appointed to Kilis.

75 Turkey has struggled with PKK terrorism for decades and has also fought with YPG, considered as its Syrian offshoot. 
by the military in authoring the security agenda had been rendered controversial. Once the politics of authoring 'national security' was exposed, the metaphorical security genie was let out of the bottle. The concept of 'securitisation' (güvenlikleştirme) became a part of Turkish language, being used not only in scholarly writings, but also by pundits in media commentaries. ${ }^{76}$ It was in such a context, characterised by an increasing awareness of the politics of security in Turkey, that sacralisation was employed by Ankara in early 2016.

One caveat here is that the fact that Ankara's invocation of 'sacred' cultural codes, in portraying the dangers as well as the suffering caused by the Kilis incident, does not indicate acceptance by the audience (be it members of the public or nonstate actors including religious leaders). After all, attempting to politicise an issue that is rendered 'sacred' by powers-that-be carries significant risks for citizens. What if they get labelled as committing sacrilege? Furthermore, the fact that religious leaders did not challenge Ankara's sacralisation of the dangers involved or suffering caused by the attacks could not be viewed as acceptance; for, they did not weigh in to offer their support either.

Ankara's response to the Kilis incident in early 2016 comes across as unanticipated, because it does not sit comfortably with either the securitisation/desecuritisation binary or the politicisation perspective. While Ankara's securitisation of the incident did not prevent the critics from attempting to generate controversy (as anticipated by the politicisation perspective), a discourse other than security-speak was utilised by the state elite to limit politics around security. Ankara's invoking of 'sacred' cultural codes, thereby limiting politics in the face of a body of critics seeking to politicise security, comes across as unanticipated for either approach.

\section{Bibliography}

Agnew, John. "Religion and Geopolitics." Geopolitics 11 (2006): 183-91. https:// doi.org/10.1080/14650040600598619

Akgül Açıkmeşe, Sinem. "EU Conditionality and Desecuritization Nexus in Turkey." Southeast European and Black Sea Studies 13, no. 3 (2013): 303-23. https://doi. org/10.1080/14683857.2013.812772

Altınay, Ayșe Gül. The Myth of the Military Nation: Militarism, Gender, and Education in Turkey. New York: Palgrave Macmillan, 2004. https://doi. org/10.1057/9781403979360

Aradau, Claudia. "Security and the Democratic Scene: Desecuritization and Emancipation." Journal of International Relations \& Development 7, no. 4 (2004): 388-413. https://doi.org/10.1057/palgrave.jird.1800030

Aradau, Claudia, \& Rens Van Munster. "Governing Terrorism through Risk: Taking Precautions,(Un) Knowing the Future." European journal of international relations 13, no. 1 (2007): 89-115. https://doi.org/10.1177/1354066107074290

Bagge Laustsen, Carsten \& Ole Wæver. "In Defence of Religion: Sacred Referent Objects for Securitization." Millennium - Journal of International Studies 29, no. 3 (2000): 705-39. https://doi.org/10.1177/03058298000290031601

76 Bilgin, "The politics of studying securitization? The Copenhagen School in Turkey." 
Berger, Peter L. The Sacred Canopy: Elements of a Sociological Theory of Religion. New York: Anchor Books, 1967.

Bigo, Didier. "International Political Sociology." In Security Studies: An Introduction, edited by Paul D. Williams, 116-29. London: Routledge, 2008.

Bilgin, Pinar. "Making Turkey's Transformation Possible: Claiming 'SecuritySpeak' - Not Desecuritization!". Journal of Southeast European and Black Sea Studies 7, no. 4 (2007): 555-71. https://doi.org/10.1080/14683850701726039

Bilgin, Pinar. "The Politics of Studying Securitization? The Copenhagen School in Turkey." Security Dialogue 42, no. 4-5 (2011): 399-412. https://doi. org/10.1177/0967010611418711

Bilgin, Pinar. "Temporalizing Security: Securing the Citizen, Insecuring the Immigrant in the Mediterranean." In Time, Temporality and Violence in International Relations: (De) Fatalizing the Present, Forging Radical Alternatives, edited by Anna M. Agathangelou and Kyle D. Killian, 221-32. London: Routledge, 2016. Booth, Ken, ed. Critical Security Studies and World Politics. Boulder: Lynne Rienner Publishers, 2005.

Booth, Ken. "Security and Emancipation." Review of International Studies 17, no. 4 (1991): 313-26. https://doi.org/10.1017/S0260210500112033

Booth, Ken. "Security and Self: Reflections of a Fallen Realist." In Critical Security Studies: Concepts and Cases, edited by Keith Krause \& Michael C. Williams. Minneapolis: University of Minnesota Press, 1997.

Booth, Ken. Theory of World Security. Cambridge: Cambridge University Press, 2007. https://doi.org/10.1017/CBO9780511840210

Burke, Anthony. "Security Cosmopolitanism." Critical Studies on Security 1, no. 1 (2013): 13-28. https://doi.org/10.1080/21624887.2013.790194

Bush, George W. "Address to the Nation on the Proposed Department of Homeland Security." Weekly Compilation of Presidential Documents 38, no. 23 (2002): 963-65.

Buzan, Barry, Ole Waever, \& Jaap De Wilde. Security: A New Framework of Analysis. Boulder, CO: Lynne Rienner, 1998.

Cawthra, Gavin \& Robin Luckham, eds. Governing Insecurity: Democratic Control of Military and Security Establishments in Transitional Democracies. Zed Books, 2003.

Cebeci, Münevver. "The EU's Impact on Turkey: Democratization as Desecuritization." In The EC/EU: a world security actor? An assessment after 50 years of the external actions of the EC/EU. European Union Institute for Security Studies (EUISS), Paris, 2006.

Cizre-Sakallığlu, Ümit. "The Anatomy of the Turkish Military's PoliticalAutonomy." Comparative politics (1997): 151-66. https://doi.org/10.2307/422077

Cole, David. "We Kill People Based on Metadata." The New York Review of Books 10 (2014): 2014.

Demerath III, Nicolas J. "Secularization and Sacralization Deconstructed and Reconstructed." In The SAGE handbook of the sociology of religion, edited by James A Beckford \& Nicholas J Demerath III, 57-80. London: Sage, 2007.

Diken, Bülent, \& Carsten Bagge Laustsen. "“We Two Will Never Twin”: Fundamentalism and the Politics of Security." Global Society 20, no. 2 (2006): 199-221. https://doi.org/10.1080/13600820600576449 
Dillon, Michael. Politics of Security: Towards a Political Phiosophy of Continental Thought. Routledge, 2002.

Erguvenc, Sadi. "Turkey's Security Perceptions." Perceptions 3, no. 2 (1998).

Fierke, K. M. Critical Approaches to International Security. 2nd ed. Oxford: Wiley, 2015.

Fine, Elizabeth C. \& Jean Haskell Speer. "Tour Guide Performances as Sight Sacralization." Annals of tourism research 12, no. 1 (1985): 73-95. https://doi. org/10.1016/0160-7383(85)90040-4

Gentile, Emilio, \& Robert Mallett. "The Sacralisation of Politics: Definitions, Interpretations and Reflections on the Question of Secular Religion and Totalitarianism." Totalitarian movements and political religions 1, no. 1 (2000): 18-55. https://doi.org/10.1080/14690760008406923

Guzzini, Stefano. "The Dual History of 'Securitisation'." In DIIS working paper. Copenhagen: Danish Institute for International Studies, 2015.

Holm, Ulla. "The EU's Security Policy Towards the Mediterranean: An (Im)Possible Combination of Export of European Political Values and Anti-Terror Measures?" DIIS Working Papers, no. 2004/13 (2004).

Hurd, Elizabeth Shakman. "Political Islam and Foreign Policy in Europe and the United States." Foreign Policy Analysis 3, no. 4 (2007): 345-67. https://doi. org/10.1111/j.1743-8594.2007.00054.x

Hurd, Elizabeth Shakman. The Politics of Secularism in International Relations. Princeton: Princeton University Press, 2008.

Hutchinson, John. "Warfare and the Sacralisation of Nations: The Meanings, Rituals and Politics of National Remembrance." Millennium 38, no. 2 (2009): 401-17. https://doi.org/10.1177/0305829809347538

Kadercan, Burak. "What the ISIS Crisis Means for the Future of the Middle East." In Non-State Armed Actors in the Middle East: Geopolitics, Ideology, and Strategy, edited by Murat Yeșiltaș \& Tuncay Kardaș, 237-60. Cham: Springer International Publishing, 2018. https://doi.org/10.1007/978-3-319-55287-3_11

Keyman, E. Fuat, \& Senem Aydın Düzgit. "Europeanization, Democratization and Human Rights in Turkey." In Turkey and the European Union: Prospects for a Difficult Encounter, edited by Esra LaGro \& Knud Erik Jørgensen, 69-89. London: Palgrave Macmillan UK, 2007. https://doi.org/10.1057/9780230223035 5

Kratochwil, Friedrich. "Religion and (Inter-)National Politics: On the Heuristics of Identities, Structures, and Agents." Alternatives 30, no. 2 (2005): 113-40. https://doi.org/10.1177/030437540503000201

Kratochwil, Friedrich. "Politics, Law, and the Sacred: A Conceptual Analysis." In Semantics of Statebuilding, edited by Nicolas Lemay-Hébert, Nicholas Onuf, Vojin Rakić and Petar Bojanić, 49-70. London: Routledge, 2013.

Kubálková, Vendulka. "Toward an International Political Theology." In Religion in International Relations: The Return from Exile, edited by Pavlos Hatzopoulos \& Fabio Petito, 79-105. London: Palgrave Macmillan, 2003.

Laustsen, Carsten Bagge, and Ole Wæver. "In Defence of Religion: Sacred Referent Objects for Securitization." Millennium: Journal for International Studies 29 (2000): 705-39. https://doi.org/10.1177/03058298000290031601

Lindsay, V. Jane. "Learning from Their Mistakes: Some Implications of International Relations Scholarship for the Study of Religion." Journal of Contemporary 
Religion 29, no. 2 (2014): 203-18. https://doi.org/10.1080/13537903.2014.903 666

Mavelli, Luca. "Security and Secularization in International Relations." European Journal of International Relations 18, no. 1 (2011): 177-99. https://doi. org/10.1177/1354066110396592

McSweeney, Bill. Security, Identity and Interests: A Sociology of International Relations. Cambridge University Press, 1999. https://doi.org/10.1017/ CBO9780511491559

Moro, Renato. "Religion and Politics in the Time of Secularisation: The Sacralisation of Politics and Politicisation of Religion." Totalitarian Movements and Political Religions 6, no. 1 (2005): 71-86. https://doi.org/10.1080/14690760500099796

Okyay, Asli S. “Turkey's Post-2011 Approach to Its Syrian Border and Its Implications for Domestic Politics." International Affairs 93, no. 4 (2017): 829-46. https:// doi.org/10.1093/ia/iix068

Özcan, Gencer. "Doksanlarda Türkiye'nin Ulusal Güvenlik Ve Dış Politikasında Askeri Yapının Artan Etkisi.” In En Uzun on Yll, Türkiye’nin Ulusal Güvenlik Ve Dış Politika Gündeminde Doksanlı Ylllar, edited by Gencer Özcan \& Şule Kut, 67-101. İstanbul: Büke, 2000.

Gencer Özcan, "Milli Güvenlik Kurulu', in Almanak Türkiye 2005: Güvenlik Sektörü ve Demokratik Gözetim." edited by Ümit Cizre, 32-45. İstanbul: TESEV, 2005.

Pavković, Aleksandar. "Sacralisation of Contested Territory in Nationalist Discourse: A Study of Milošević's and Putin's Public Speeches." Critical Discourse Studies 14, no. 5 (2017): 497-513. https://doi.org/10.1080/17405904.2017.1360191

Petito, Fabio, and Pavlos Hatzopoulos, eds. Religion in International Relations: The Return from Exile. London: Palgrave Macmillan, 2003.

Poitras, Laura. "Citizenfour": Praxis Films, 2014.

Spence, David, \& Philipp Fluri eds., The European Union and Security Sector Reform. Geneva: DCAF and John Harper Pub., 2008.

Tank, Pinar. "Turkey as a 'Special Case' for the EU - Will the Generals Retreat from Politics?”. Security Dialogue 32, no. 2 (2001): 217-30. https://doi.org/10.1177/ 0967010601032002007

Türkmen, İlter. "Güvenlik, Ekonomi Ve Dis Politika." Foreign Policy (Turkey) (2001): 58-65.

Waever, Ole. "Insecurity, Security, and Asecurity in the West European Non-War Community." In Security Communities, edited by Emanuel Adler \& Michael N. Barnett, 69-118. Cambridge: Cambridge University Press, 1998.

Waever, Ole. "Securitization and Desecuritization." In On Security, edited by Ronnie D. Lipschutz, 46-86. New York: Columbia University Press, 1995.

Waever, Ole. "Security, the Speech Act: Analysing the Politics of a Word." In COPRI Working Paper. Copenhagen: Copenhagen Peace Research Institute, 1989.

Walker, R. B. J. "The Subject of Security." In Critical Security Studies: Concepts and Cases, edited by Keith Krause \& Michael C. Williams, 61-81. Minneapolis: University of Minnesota Press, 1997.

Weldes, Jutta, Mark Laffey, Hugh Gusterson, \& Raymond (eds.) Duvall. Cultures of Insecurity: States, Communities and the Production of Danger. Minneapolis: University of Minnesota Press, 1999. 
Yalcinkaya, Haldun. "Foreign Fighters of ISIS and Their Security Threat: Turkey's Experience (2014-2016)." Uluslararasi Iliskiler-International Relations 14, no. 53 (2017): 23-43.

Zúquete, José Pedro. "The Missionary Politics of Hugo Chávez." Latin American Politics and Society 50, no. 1 (2008): 91-121. https://doi.org/10.1111/j.15482456.2008.00005.x 